\title{
SISTEM PEMESANAN RUMAH MAKAN XYZ BERBASIS DESKTOP
}

\author{
Dafid $^{* 1}$, Novan Wijaya ${ }^{2}$ \\ ${ }^{1}$ Program Studi Sistem Informasi, STMIK Global Informatika MDP, Palembang \\ ${ }^{2}$ Program Studi Manajemen Informatika, AMIK MDP, Palembang \\ ${ }^{1,2}$ Jalan Rajawali No.14 Palembang (0711)376400

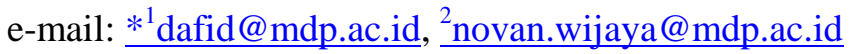

\begin{abstract}
Abstrak
Rumah makan XYZ yang berada di kota Palembang merupakan sebuah usaha penjualan makanan dan minuman dalam bentuk kuliner. Rumah makan XYZ sendiri masih menggunakan prosedur yang masih manual dalam kegiatan operasional, seperti dalam pemesanan makanan, minuman, maupun dalam proses pemesanan meja makan. Sistem yang kami kembangkan untuk rumah makan XYZ bertujuan untuk meminimalisir kesalahan yang akan terjadi pada saat proses pemesanan makanan, minuman, proses pembayaran, maupun pelaporan baik itu pelaporan yang dilakukan perhari ataupun perbulan. Adanya aplikasi ini diharapkan dapat mempermudah dalam melihat laporan seperti makanan dan minuman apa saja yang sering dipesan oleh para pengunjung. Sementara untuk metodologi yang digunakan dalam proses pembuatan aplikasi pemesanan makanan dan minuman ini menggunakan model itterative dimana setiap fase dari pengembangan sistem dilaksanakan secara berulang-ulang sampai mendapatkan hasil yang diinginkan.
\end{abstract}

Kata kunci: Aplikasi, Pemesanan, Pembayaran, Itterative Model

\begin{abstract}
XYZ restaurant located in Palembang is a food and beverage sales business in the form of culinary. $\mathrm{XYZ}$ restaurant itself still uses procedures that are still manual in operational activities, such as ordering food, drinks, or in the process of ordering a table. The system that we have developed for XYZ restaurants aims to minimize errors that will occur during the process of ordering food, drinks, payment processes, and reporting whether the reporting is done daily or monthly. The existence of this application is expected to make it easier to see reports such as what foods and drinks are often ordered by visitors. While the methodology used in the process of making food and beverage ordering applications uses an itterative model where each phase of system development is carried out repeatedly until the desired results are obtained
\end{abstract}

Keywords: Applications, Reservations, Payment. Itterative Model

\section{PENDAHULUAN}

Rumah Makan (RM) XYZ ialah rumah makan yang terfokus pada proses penjualan makanan dan minuman. Pada kegiatan yang terjadi pada RM XYZ, masih menggunakan proses pemesanan makanan dan minuman secara manual seperti masih menggunakan kertas dan pena pada saat pemesanan sehingga sangat memungkinkan terjadi kesalahan baik dalam proses pemesanan, pengantaran makanan bahkan pada saat proses pembayaran. Kesalahan-kesalahan yang akan terjadi dikarenakan proses manual tersebut bisa berdampak pada proses pembuatan laporan, baik itu laporan yang dikerjakan perhari maupun laporan yang akan dikerjakan perbulan.
Sistem yang bersifat manual ini dinilai tidak efektif dan efisien di era globalisasi saat ini. Berdasarkan dari permasalahan yang terjadi di RM. XYZ maka kami mencoba membuat sebuah aplikasi yang terfokus pada proses pemesanan makanan dan minuman, proses pembayaran serta proses pembuatan laporan kepada manajemen dari RM. XYZ. Adapun sistem yang akan dibangun yaitu "Sistem Pemesanan Rumah Makan XYZ Berbasis Desktop". 


\section{TINJAUAN PUSTAKA}

\subsection{Aplikasi}

Aplikasi ialah serangkaian prosedur yang berisikan instruksi-instruksi program dengan menggunakan bahasa pemrograman yang dikonversi kedalam bahasa mesin sehingga bisa diterjemahkan oleh komputer [1].

2.2 Pemesanan

Pemesanan adalah proses, perbuatan, cara memesan atau memesankan baik itu berupa barang atau jasa. [2].

2.3 Merode Iterasi

Itterative model merupakan sebuah metodologi dimana pada setiap fase akan dilakukan proses secara berulang-ulang[3]. Adapun tahapan-tahapan dari metodologi ini yaitu sebagai berikut dan dapat dilihat pada gambar 1 [5] :

1. Tahapan Analisis

Proses tahap ananlisis yang akan dikerjakan dengan mengumpulkan data yang akan dipergunakan untuk kepentingan dalam proses pembutan sistem. Data yang didapatkan pada proses analisis ini akan menjadikan batasan sistem yang akan dibuat.

\section{Tahap Perancangan}

Proses percangan bertujuan memberikan gambaran yang dikerjakan dan tampilan antar muka aplikasi yang membantu mendefinisikan kebutuhan perangkat lunak dan sistem secara keseluruhan.

3. Tahap Pembuatan Kode Program

Tahap ini yang dilakukan yaitu menerapkan rancangan aplikasi yang dibuat kedalam bentuk program. Hasil dari tahap ini harus sesuai dengan perancangan yang dibuat untuk tahap perancangan selanjutnya.

4. Tahap Pengujian

Tahap yang dilakukan berfokus pada perangkat lunak dan memastikan semua bagian telah diuji dan untuk mengurangi kesalahan

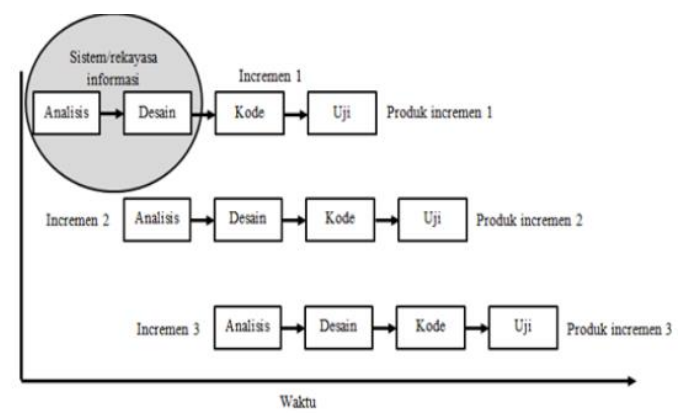

Gambar 1. Itterative Model [5]

\subsection{Data Flow Diagram}

Diagram alir data (DAD) merupakan sebuah proses yang digambarkan dalam bentuk aliran data berupa informasi baik itu berupa masukkan dan keluaran kepada sistem yang akan dibuat[6].

2.5 Diagram Konteks

Diagram konteks akan menjelaskan external entity apa saja yang terlibat di sistem yang di buat[6].

\subsection{Entity Relationship Diagram}

ERD menggambarkan entitas-entitas yang saling berhubunga dengan entitas lain pada sistem yang akan dibuat[7].

2.7 Flowchart

Flowchart bertujuan memudahkan dalam proses perancangan alur pada saat sistem akan diimplementasikan dalam bentuk program baik itu kesalahan dalam prosedur maupun kesalahan dalam proses program[8].

\section{METODE PENELITIAN}

3.1 Prosedur yang Berjalan

Adapun proses yang terjadi pada saat ini di RM. XYZ :

Untuk mendapatkan pemahaman terhadap aktivitas suatu sistem, maka diperlukan beberapa uraian yang berhubungan dengan prosedur yang berjalan pada Rumah Makan XYZ, mempunyai beberapa tahapan dalam melakukan proses pemesanan makanan dan minuman yang dapat dilihat pada gambar 2 dengan rincian sebagai berikut :

1. Pelanggan yang telah datang dan mendapatkan meja makan yang sesuai, akan melakukan proses pemesanan makanan dan minuman dengan cara pelayan yang akan mendekati pelanggan dan mencatat pesanan dari pelanggan tersebut.

2. Pesanan yang telah dicatat berupan nota kertas, akan diberikan kepada bagian dapur.

3. Pada bagian dapur akan dibuat sesuai dengan nota yang telah diberikan oleh pelayan.

4. Makanan dan minuman yang telah siap, diberikan kembali kepada pelayan berdasarkan nota yang diberikan sebelumnya.

5. Pelayan akan mengantarkan pesanan tersebut kepada pelanggan, sesuai dengan nomor meja yang tertera pada nota pemesanan.

6. Setelah makanan dan minuman diantarkan kepada pelanggan, pelayan akan memberikan nota pemesanan tersebut kepada kasir. 
7. Pelanggan melakukan proses pembayaran langsung kepada kasir dengan menyebutkan nomor meja.

8. Kasir akan memberikan nota pembayaran kepada pelanggan.

9. Kasir memberikan laporan penjualan kepada pemilik berupa nota pembayaran setiap hari.

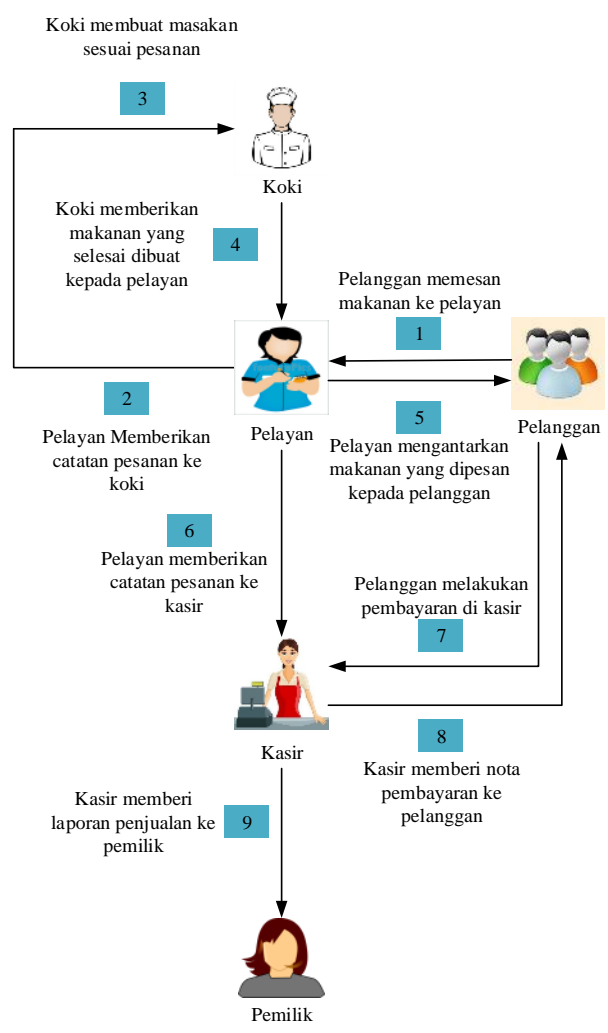

Gambar 2. Prosedur yang sedang berjalan

3.2 Prosedur yang Diusulkan

Sementara untuk prosedur yang akan dilakukan dengan menggunakan sistem terhadap proses pemesanan, pembayaran, dan pelaporan sebabagi berikut :

1. Proses pemesanan makanan dan minuman

a. Pelanggan bisa memesan nomor meja sesuai dengan keinginan melalui menelepon langsung ke RM. XYZ.

b. Nota pesanan yang telah dipilih oleh pelanggan melalui pelayan, akan dimasukkan kedalam sistem dengan memasukkan nomor meja pelanggan yang memesan, makanan, dan minuman.

c. Bagian dapur akan melihat pada sistem, makanan dan minuman apa yang telah dipesan dan akan segera dibuatkan.

d. Bagian dapur akan memberikan notifikasi pada sistem jika pesanan yang dipesan telah selesai dikerjakan. e. Pelayan mendapatkan notifikasi pesanan telah selesai dan mengantarkan pesanan tersebut kepada pelanggan berdasarkan nomor meja yang memesan.

2. Proses pembayaran

a. Pelanggan dapat langsung melakukan proses pembayaran, dengan hanya menyebut nomor meja makan dimana pelanggan tersebut duduk.

b. Bagian kasir akan memasukkan nomor meja makan pelanggan kemudian memberikan nota pemnayaran kepada pelanggan tersebut.

3. Proses laporan

a. Pemilik bisa langsung melihat laporan penjualan baik itu menu yang paling sering dipesan sampai laporan keuangan yang terjadi secara real time.

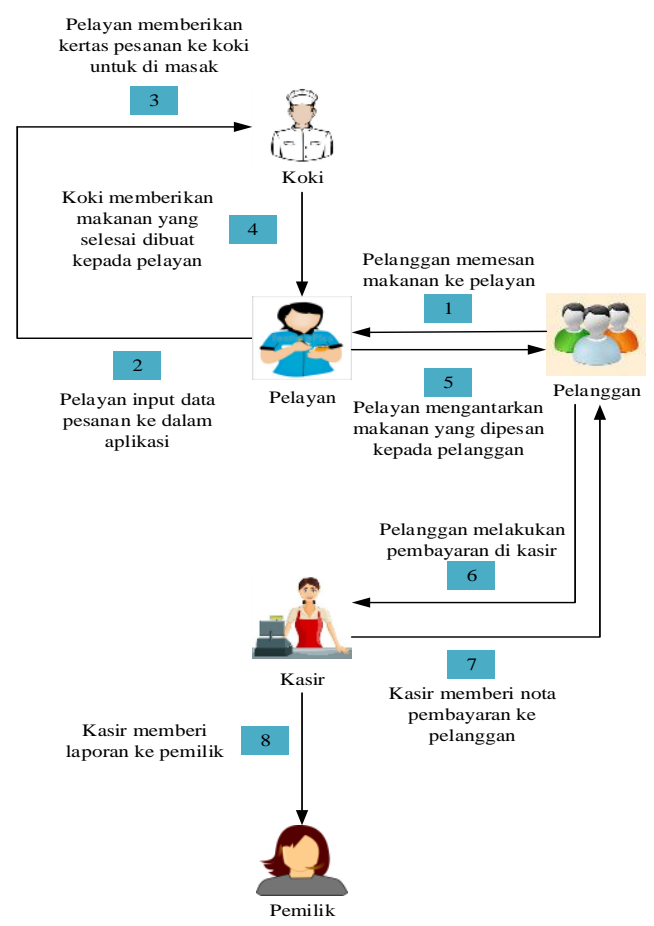

Gambar 3. Prosedur yang akan diusulkan 
3.3 Rancangan Basis Data

ERD menjelaskan hubungan antar abel yang terjadi pada RM. XYZ (Gambar 4).

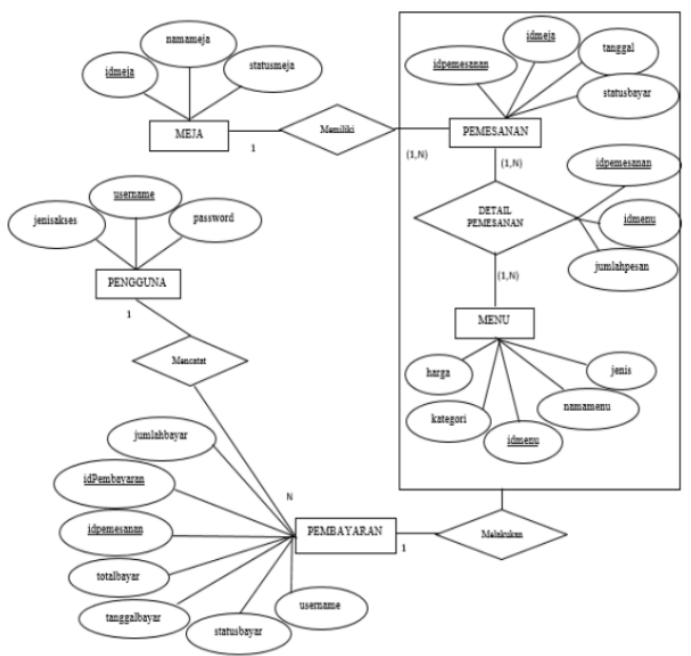

Gambar 4. Rancangan Basis Data

3.4 Rancangan Proses

3.4.1 Diagram Konteks Yang Diusulkan Diagram konteks sistem yang diusulkan dapat dilihat pada gambar 5 .

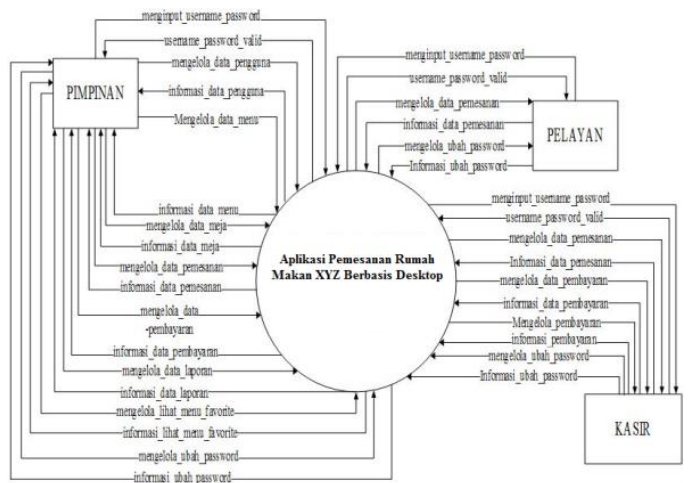

Gambar 5. Diagram Konteks Yang Diusulkan

3.4.2 Diagram Nol Yang Diusulkan

Diagram Nol merupakan level kedua dari DFD yang menggambarkan rincian dari diagram konteks. Diagram aliran data sistem dapat dilihat pada gambar 6 .

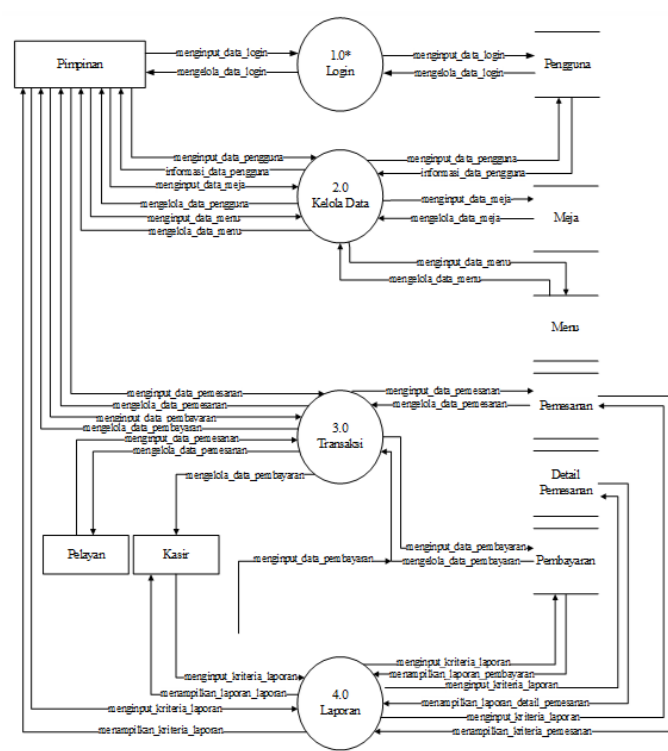

Gambar 6. Diagram Nol Yang Diusulkan

3.4.3 Diagram Rinci 1.1

Pada gambar 7 menunjukkan kejadian pada sistem yang diusulkan dari aliran data login.

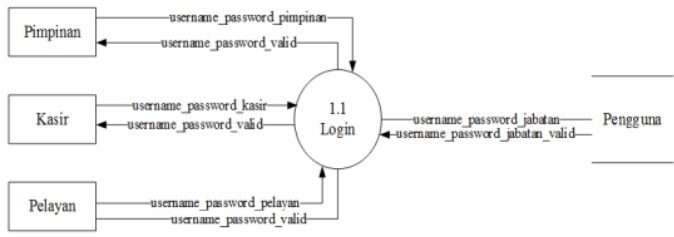

Gambar 7 Digaram Rinci 1.1

3.4.4 Diagram Rinci 2.1

Pada gambar 8 menunjukkan kejadian pada sistem yang diusulkan dari aliran data kelola data.

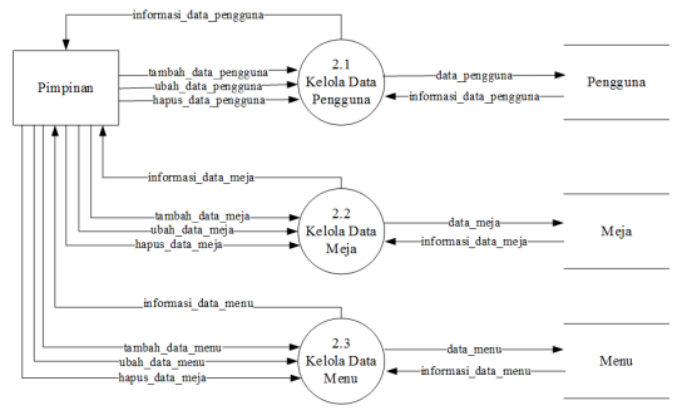

Gambar 8 Diagram Rinci 2.1 


\subsubsection{Diagram Rinci 3.1}

Pada gambar 9 menunjukkan kejadian pada sistem yang diusulkan dari aliran data Transasksi.

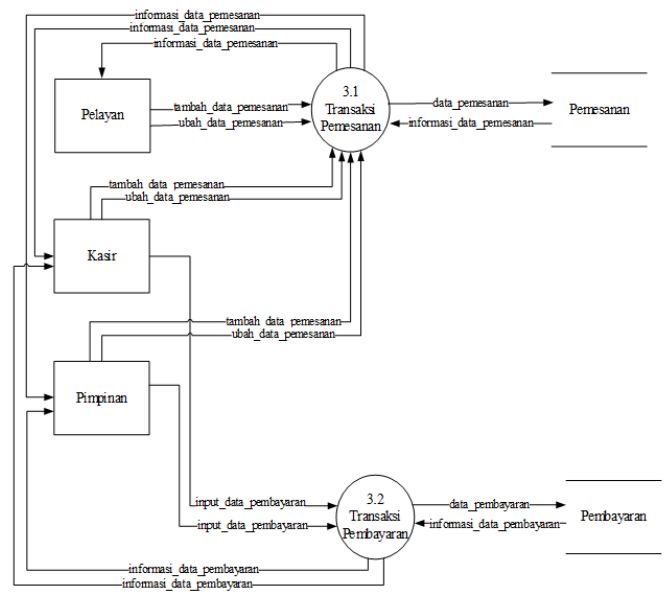

Gambar 9. Diagram Rinci 3.1

3.4.6 Diagram Rinci 4.1

Pada gambar 10 menunjukkan kejadian pada sistem yang diusulkan dari aliran data Laporan.

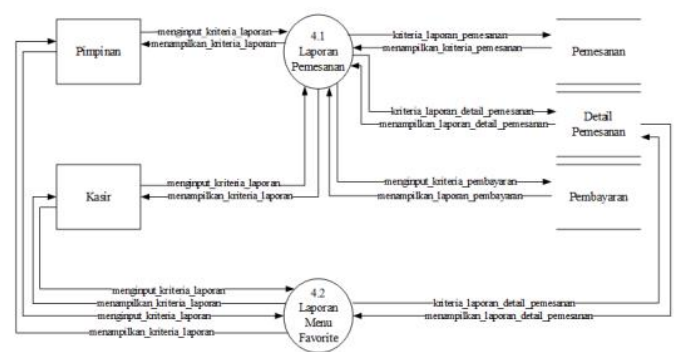

Gambar 10. Diagram Rinci 4.1

\subsection{Flowchart}

Bagan alir (flowchart) yaitu bagan yang menunjuk sebuah akliran dalam program atau prosedur sistem secara logika [9]. Bagan alir ini merupakan bagan yang menjelaskan secara rinci langkah-langkah dari setiap proses program yang berjalan. Untuk flowchart login dapat dilihat pada gambar 11, flowchart pemesanan dapat dilihat pada gambar 12, flowchart pembayaran dapat dilihat pada gambar 13, dan untuk flowchart laporan dapat dilihat pada gambar 14.

\subsubsection{Flowchart Login}

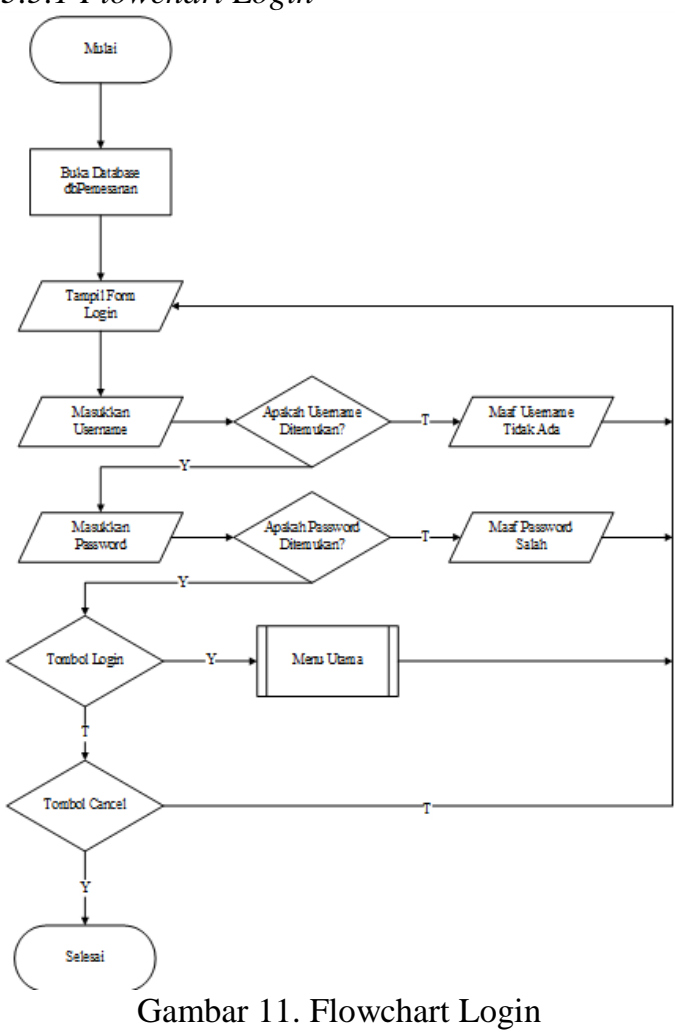

3.5.2 Flowchart Pemesanan

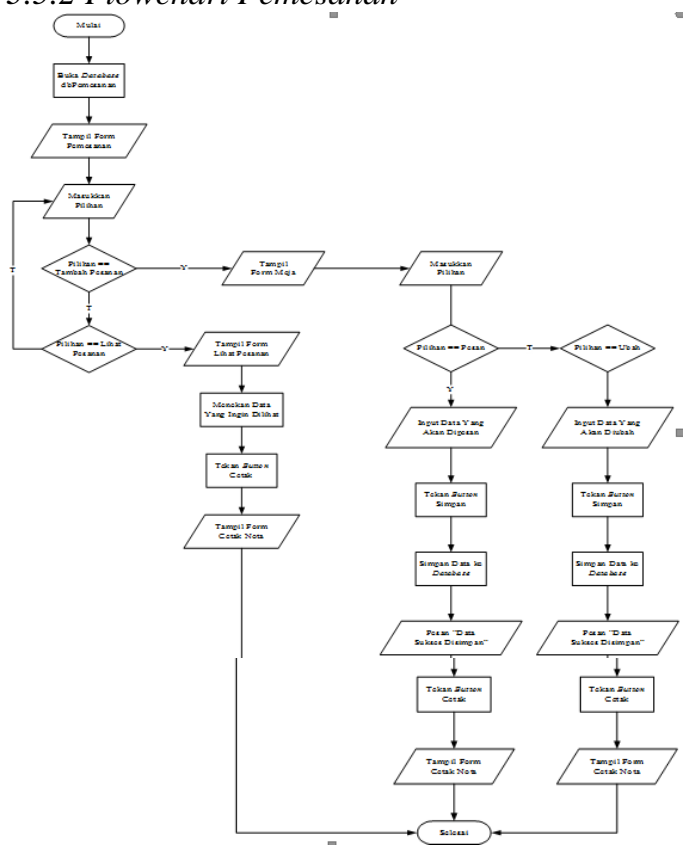

Gambar 12. Flowchart Pemesanan 


\subsubsection{Flowchart Pembayaran}

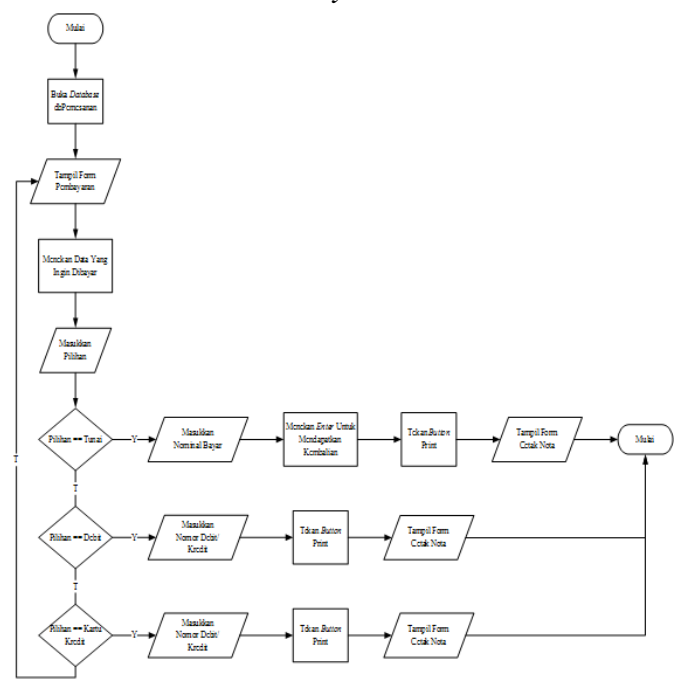

Gambar 13. Flowchart Pembayaran

\subsubsection{Flowchart Laporan}

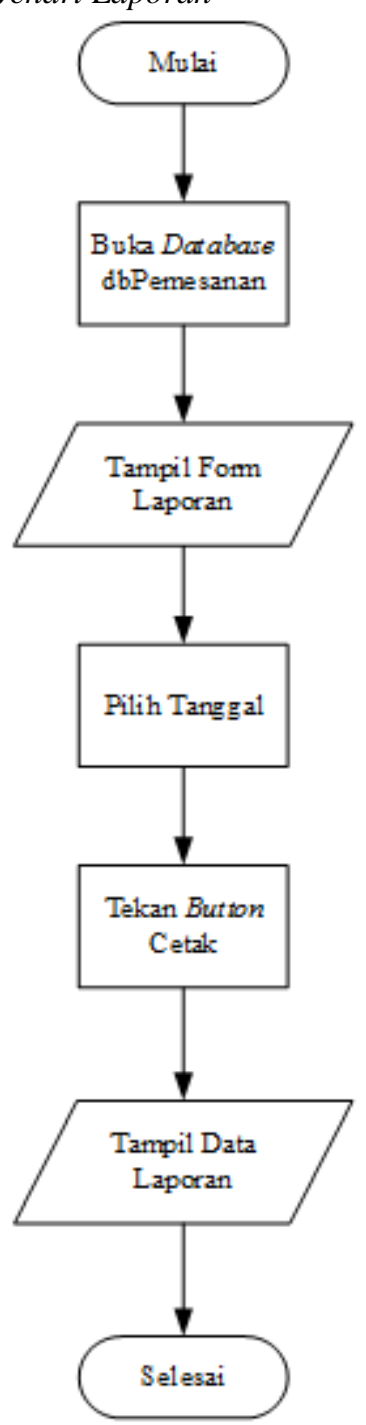

Gambar 14. Flowchart Laporan
3.5 Rancangan Dialog Layar

Rancangan dialog layar adalah susunan pada form program yang dibuat. Rancangan ini berisi tampilan dialog layar yang dibutuhkan sistem yang akan dibuat. Rancangan ini berisi tampilan dalam bentuk struktur pada aplikasi program. Struktur tampilan dapat dilihat pada gambar 15 .

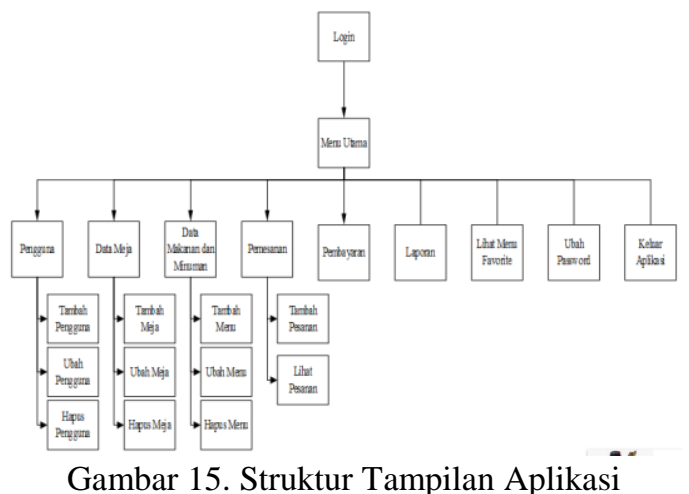

Struktur tampilan program, menerangkan bahwa pada bagian login adalah untuk pengguna masuk ke dalam menu utama. Pada bagian menu utama terdapat 9 pilihan, yaitu: pengguna, data meja, data makanan dan minuman, pemesanan, pembayaran, laporan, lihat menu favorite, ubah password, dan keluar aplikasi. Pada bagian pengguna terdiri dari tambah pengguna, ubah pengguna, hapus pengguna. Pada bagian meja terdiri dari tambah meja, ubah meja, dan hapus meja. Pada bagian data makanan dan minuman terdiri dari tambah menu, ubah menu, dan hapus menu. Pada bagian pemesanan terdiri dari tambah pesanan dan lihat pesanan. Pada bagian pembayaran berguna untuk melakukan transaksi pembayaran. Pada bagian laporan berguna untuk mencetak transaksi pemesanan. Pada bagian lihat menu favorite berguna untuk melihat menu apa saja yang sering dipesan. Pada bagian ubah password berguna untuk mengubah password pemakai atau pengguna. Dan pada bagian keluar aplikasi berguna untuk keluar dari aplikasi

\section{HASIL DAN PEMBAHASAN}

4 Rancangan Antar Muka Program

4.1 Tampilan Menu Login

Bagian form login teradapat username dan password yang terbagi menjadi 2 yaitu username sebagai pemilik rumah makan dan username sebagai karyawan pada rumah makan XYZ, ini dapat dilihat pada gambar 16 . Username ini yang akan menjadi pembeda ketika akan menggunakan aplikasi, pemilik rumah makan mempunyai hak akses penuh pada 
aplikasi sementara untuk karyawan yang menggunakan aplikasi akan mendapatkan batasan-batasan saat membuka aplikasi.

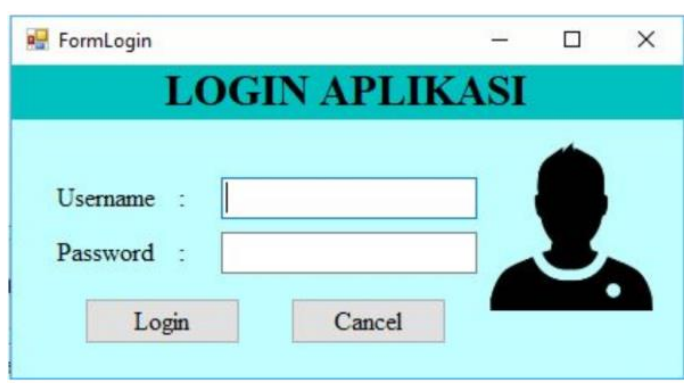

Gambar 16. Tampilan Menu Login

4.2 Tampilan Menu Pemesanan

Bagian form pemesanan berfungsi untuk memasukkan daftar pesanan. Terdapat beberapa field yang harus diisi pada form ini, yaitu: cari menu makanan atau minuman, jumlah yang akan dipesan. Serta terdapat beberapa button, yaitu: tambah, hapus, simpan, tutup, dan cetak. Rancangan form pemesanan dapat dilihat pada gambar 17.

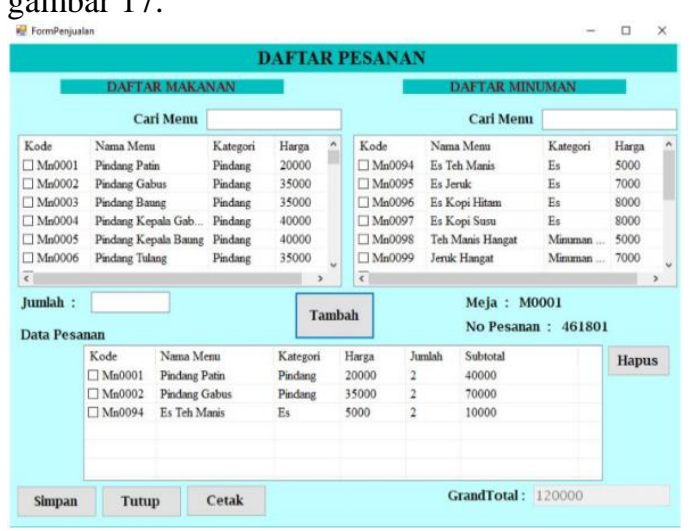

Gambar 17. Tampilan Menu Pemesanan

4.3 Tampilan Menu Pembayaran

Bagian form pembayaran berfungsi untuk memasukkan pembayaran sesuai nomor pesanan dan nomor meja. field yang harus diisi pada form ini, nominal bayar. Serta terdapat button tutup dan print. Rancangan form pembayaran dapat dilihat pada gambar 18 .

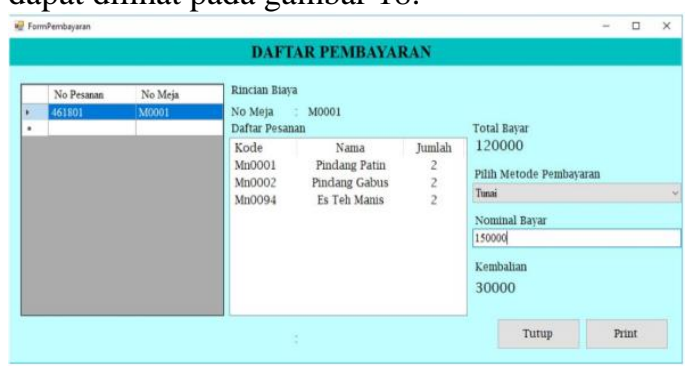

Gambar 18. Tampilan Menu Pembayaran

4.4 Tampilan Menu Meja
Bagian form pada menu meja diperlukan ketika para pelanggan yang akan memesanan makanan dan minuman, karyawan akan memasukkan nomor meja sang pelanggan kedalam aplikasi. Sehingga pelanggan yang baru datang ke rumah makan akan diarahkan ke meja yang kosong. Form ini juga berfungsi agar pelanggan dapat memesan meja yang diinginkan ketika akan makan pada rumah makan XYZ. Rancangan untuk tampilan menu meja dapat dilihat pada gambar 19.

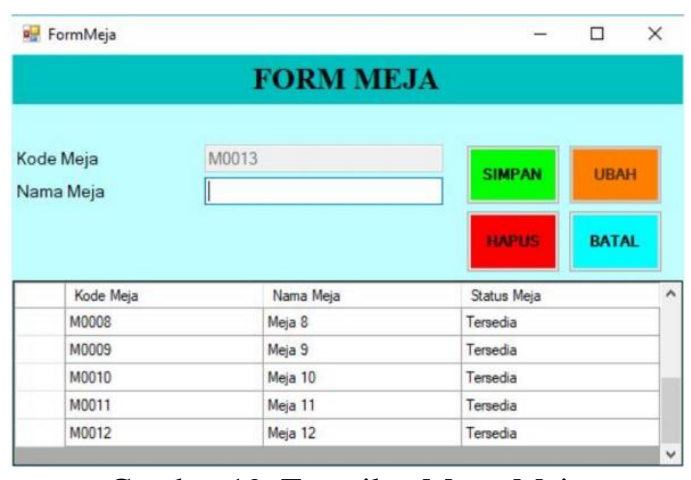

Gambar 19. Tampilan Menu Meja

4.5 Tampilan Menu Cetak Laporan

Pada gambar 20 merupakan salah satu contoh dari laporan yang didapatkan dari aplikasi tetapi berupa laporan harian. Untuk jenis pelaporan sendiri dibagi menjadi 3 yaitu laporan harian, laporan mingguan, dan laporan bulanan.

\begin{tabular}{|c|c|c|c|c|c|}
\hline \multicolumn{6}{|c|}{ APLIKASI PEMESANAN RUMAH MAKAN XYZ } \\
\hline \multicolumn{3}{|c|}{ So Pesmesaran : 461801} & \multicolumn{2}{|c|}{ Tanggal Transaksi } & $: 2018.0604$ \\
\hline Kode Menum & Nama Mear & Kategon & Sumiah & Hang & sabtoot \\
\hline monoot & Pindang Patin & Pindang & ${ }^{2}$ & 20.000 & $40,000,00$ \\
\hline Mnooo2 & Pindeng Gabus & Pindeng & 2 & 35.000 & 70000000 \\
\hline unooses & Es Toh Maris & Es & 2 & 5000 & 10000000 \\
\hline
\end{tabular}

Gambar 20. Tampilan Menu Cetak Laporan 4.6 Tabel Hasil Pengujian

Adapun hasil pengujian yang dilakukan terhadap aplikasi yang telah dibuat dapat dilihat pada Tabel 1 sebagai berikut:

Tabel 1. Tabel Hasil Pengujian

\begin{tabular}{lrl}
\hline \multicolumn{2}{c}{ Skenario Pengujian } & \multicolumn{2}{c}{ Hasil Pengujian } \\
\hline \multicolumn{2}{l}{ Menjalankan tiap } & Sistem akan \\
menu yang terdapat & menampilkan form \\
pada sistem sesuai & sesuai dengan menu \\
hak akses yang & yang dipilih \\
dibuat & & \\
Menekan tombol & Menampilkan pesan \\
simpan ketika data & pada sistem bahwa \\
belum diisi secara & data belum lengkap \\
menyeluruh pada & \\
form &
\end{tabular}




\begin{tabular}{|c|c|}
\hline $\begin{array}{lr}\text { User } & \text { melakukan } \\
\text { proses pengisian data } \\
\text { pesanan } & \text { makanan } \\
\text { dengan } & \text { menginput } \\
\text { data } & \text { pesanan } \\
\text { makanan } & \text { dan } \\
\text { menekan } & \text { tombol } \\
\text { simpan } & \end{array}$ & $\begin{array}{l}\text { Data akan tersimpan } \\
\text { pada sistem }\end{array}$ \\
\hline $\begin{array}{lr}\text { User } & \text { melakukan } \\
\text { proses pencarian data } \\
\text { menu } \\
\text { makanan/minuman } \\
\text { dengan menginput } \\
\text { data } & \text { makanan } \\
\text { /minuman } & \text { yang } \\
\text { dicari dan } & \text { menekan } \\
\text { tombol cari }\end{array}$ & $\begin{array}{l}\text { Data } \\
\text { makanan/minuman } \\
\text { yang dicari akan } \\
\text { tampil pada layar } \\
\text { monitor }\end{array}$ \\
\hline 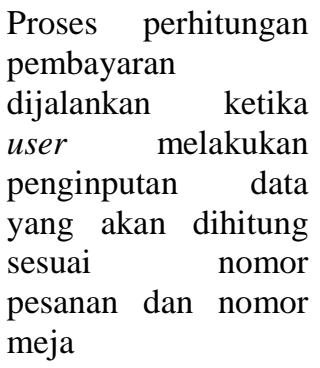 & $\begin{array}{l}\text { Hasil perhitungan } \\
\text { jumlah yang harus } \\
\text { dibayar akan tampil } \\
\text { sesuai dengan rumus } \\
\text { yang diberikan }\end{array}$ \\
\hline $\begin{array}{lr}\text { Proses } & \text { pencetakan } \\
\text { struk } & \text { pembayaran } \\
\text { dari } & \text { hasil } \\
\text { perhitungan ketika } \\
\text { user } & \text { melakukan } \\
\text { pemilihan } & \text { data dan } \\
\text { menekan } & \text { tombol } \\
\text { print } & \end{array}$ & $\begin{array}{lr}\text { Sistem } & \text { akan } \\
\text { menampilkan } & \\
\text { informasi } & \text { berupa } \\
\text { rincian } & \text { data } \\
\text { pembayaran } & \end{array}$ \\
\hline $\begin{array}{l}\text { Proses pencetakan } \\
\text { laporan yang terdiri } \\
\text { dari laporan harian, } \\
\text { laporan mingguan } \\
\text { maupun laporan } \\
\text { bulanan dari data } \\
\text { transaksi yang telah } \\
\text { tersimpan } \\
\text { sebelumnya dengan } \\
\text { menekan } \\
\text { print }\end{array}$ & $\begin{array}{l}\text { Sistem akan } \\
\text { menampilkan } \\
\text { informasi berupa } \\
\text { data laporan sesuai } \\
\text { dengan jenis laporan } \\
\text { harian, laporan } \\
\text { mingguan maupun } \\
\text { laporan bulanan }\end{array}$ \\
\hline $\begin{array}{l}\text { Memilih menu meja } \\
\text { pada form dengan } \\
\text { input nomor meja } \\
\text { pelanggan kedalam } \\
\text { aplikasi baik untuk } \\
\text { pelanggan yang baru } \\
\text { datang maupun } \\
\text { untuk meja yang } \\
\text { diinginkan }\end{array}$ & $\begin{array}{lr}\text { Sistem } & \text { akan } \\
\text { menampilkan menu } \\
\text { meja sesuai dengan } \\
\text { data yang telah } \\
\text { didefiniskan }\end{array}$ \\
\hline
\end{tabular}

\section{KESIMPULAN}

1. Sistem yang dibangun pada RM. XYZ diharapkan dapat mempermudah para stakeholder dalam melakukan proses pemesanan baik itu berupa makanan dan minuman.

2. Sistem diharapkan dapat memperkecil kesalahan yagn diakibatkan oleh human error seperti salah memasukkan nomor meja pada saat pesanan diantar.

3. Sistem diharapakan dapat mengurangi kesalahan dalam proses pembayaran.

4. Sistem diharapkan dapat membantu pemilik dalam melihat laporan pada RM. XYZ

\section{SARAN}

1. Agar dapat memperbaharui baik itu dari segi menu makanan dan minuman, maupun dari sistem operasi yang digunakan pada sistem di RM. XYZ.

2. Untuk lebih mempermudah kembali operasional, bisa dengan cara mengubah sistem berbasis desktop menjadi berbasis android sehingga pemilik bisa mengakses seluruh kegiatan operasional dimanapun dan kapanpun.

\section{DAFTAR PUSTAKA}

[1] Y. Sugiyani, V. Rosalina, and I. Yunan, "Perancangan Aplikasi Edukatif Berbasis Multimedia Untuk Memudahkan Siswa Belajar Membaca Pada Mata Pelajaran Bahasa Indonesia," PROSISKO, vol. 1, pp. 55-59, 2014.

[2] Sukarno, Gendut, and S. Sumarto, "Pengaruh Pengorbanan Dan Kualitas Layanan Terhadap Keputusan Pembelian Ulang. Ekuitas," J. Ekon. dan Keuang., vol. 9, no. 4, pp. 545-564, 2018.

[3] N. Wijaya, A. Taqwiym, and H. Irsyad, "Perancangan Pola Pembelian Saham Berdasarkan Pekerjaan Nasabah Dengan Metode Association Rule Pt XYZ," J. Tek. Inform. (JUTIMO, vol. 2, no. 1, pp. 32-43, 2017.

[4] M. Salahuddin and A. S. Rosa, Modul Pembelajaran Rekayasa Perangkat Lunak (Terstruktur dan Berorientasi Objek). Bandung: Modula, 2011.

[5] H. Al Fatta, Analisis dan Perancangan Sistem Informasi. Yogyakarta: Andi Offset, 2007.

[6] N. Wijaya, "Perancangan Aplikasi Promosi Songket Palembang Berbasis Android," JUSIM, vol. 2, no. 2, pp. 10- 
22, 2017.

[7] H. Irsyad, A. Taqwiym, and N. Wijaya, "Smart Tourism Information And Management (Saritem) Kota Palembang Berbasis Android," Computatio, vol. 2, no. 1, pp. 23-35, 2018.

[8] T. . Hathaway, Data Flow Diagram by Example. USA: BA-Experts, 2015.

[9] Fransisca, Imelda, and Dafid, "Sistem Informasi Manajemen Hubungan

Pelanggan Pada Pt. Xyz Palembang," J. Technol. Accept. Model, vol. 8, no. 1, pp. 1-7, 2017. 